\title{
Removal of Aromatic Hydrocarbons Pollutants From Oilfield Wastewater COD By Oxidation-coagulation Process
}

\author{
Wu Chen ${ }^{1,2, a}$, Shan-Hui Zhang ${ }^{1,2, b}$, Nan-Xi Lin 1,2,c, \\ Zu-Lin Chen ${ }^{3, d}$, Yang Liu ${ }^{1,2, e}$, Bai-Chun Wu, $\mathrm{Wu}^{2, \mathrm{f}}$
}

${ }^{1}$ School of Chemistry and Environmental Engineering, Yangtze University, Jingzhou 434023, China

${ }^{2}$ State Key Laboratory of control and treatment of petroleum and petrochemical pollutants, BeiJin,102206, China

${ }^{3}$ College of Resources and Environment, Yangtze University, WuHan , 430100,China

aemail:chenwu@@yangtzeu.edu.cn, bemail:1025965276 @qq.com, cemail: 491261046@qq.com

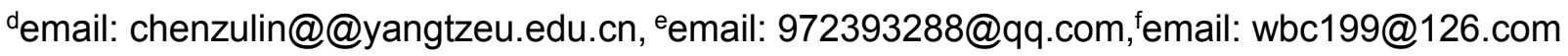

Biography: Wu Chen (1967-), male, Ph. D., Professor of Yangtze University, mainly engaged in the oilfield wastewater treatment.

Corresponding author: Zu-Lin Chen (1973-), male, Ph. D., Lecturer of Yangtze University, mainly engaged in the geochemistry research and teaching .

Keywords oxidation-coagulation; wastewater from oilfield; chemical oxygen demand (COD) ; aromatic hydrocarbons pollutants ; water-treatment.

Abstract This paper mainly study the mechanism of removing COD of oilfield wastewater by oxidation, coagulation and oxidation-coagulation. The results show that with the increase of oxidant 1\# dosage, the total content of the organic matter in wastewater reduces with removal rate of organic matter significantly correlated with the organic molecular structure. The highest removal rate of COD is $53.38 \%$ by single oxidation, and the oxidation can remove the pentacyclic organic matter $(100 \%)$, the bicyclic organic matter $(90.6 \%)$, tricyclic organic matter $(49.48 \%)$, and tetracycline organic matter $(38.45 \%)$ in wastewater. With the increase of coagulant $1 \#$ dosage, the total aromatic organic matter content decreased in wastewater with the removal rate of organic matter significantly correlated with the organic molecular structure and solubility (polar). The highest removal rate of wastewater COD is $42.78 \%$ by single coagulation, which can remove tricyclic organic matter $(82.74 \%)$, the pentacyclic compounds $(78.64 \%)$, tetracycline organic matter $(74.93 \%)$, and the organic matter $(73.35 \%)$ in wastewater. The highest removal rate of wastewater COD is $87.82 \%$ by oxidation-coagulation, which can remove the pentacyclic organic matter (100\%); the tetracyclic matter(93.89\%), tricyclic organic matter $(91.87 \%)$, and bicyclic organic matter $(77.69 \%)$ in wastewater. The results show that coagulation-oxidation can improve processing efficiency in organic wastewater, the mechanism of which may be interaction of substituted, oxidation, coagulation and stability, adsorption and precipitation, etc.

\section{Introduction}

COD is an important indicator of water pollution control in our country. At present, the COD content in wastewater is reduced mainly by the physical, chemical or biological methods to reduce the environment pollution of water. Coagulation is an economical and convenient water treatment method, which improves the efficiency of wastewater treatment. In most cases It is used with other treatment methods ${ }^{[1,2]}$. Jing Guolin ${ }^{[3]}$ used the oxidation combined with coagulation method to reduce the COD of Daqing oilfield operation wastewater to $440 \mathrm{mg} / \mathrm{L}$ from $3788 \mathrm{mg} / \mathrm{L}$ with the removing rate $88 \%$. At present, domestic and foreign researches on wastewater COD focus on the determination methods and removal methods, few on the mechanism of the removal of COD. Miao 
Zongcheng ${ }^{[4]}$ et al thought that potassium ferrate can strongly remove COD, which mainly relies on the multi phase flocculation function of the $\mathrm{Fe}(\mathrm{OH})_{3}$ with an assistant function of its strong oxidation. By treating organic wastewater with coal cinder as coagulant, Wang $\mathrm{Yu}{ }^{[5]}$ found that polycyclic aromatic hydrocarbons in wastewater were removed mainly through single molecule adsorption. Liu Jinquan ${ }^{[6]}$ studied the reaction mechanism of $\mathrm{ClO}_{2}$ oxidizing anthracene which showed that the oxidation reaction was an endothermic process which can occur under conventional water treatment conditions. The study on the COD wastewater treatment by oxidation coagulation process mainly focused on the methods ${ }^{[7-9]}$, with fewer qualitative studies on the removal mechanism. Liu hong ${ }^{[10]}$ has used coupled flocculation and oxidation process to treat acid brilliant scarlet dye wastewater. The results showed that acid brilliant scarlet GR is oxidized into small organic molecules by potassium permanganate, which are adsorbed by the reduction product - newly formed hydrous manganese dioxide, and is enwrapped by poly - silicic - ferric sulfate. Synergistic effect between oxidation and flocculation aggregates the color and COD are removed efficiently. Zhang Huiqin ${ }^{[11]}$ studied degradation and degradation mechanism of printing and dyeing wastewater and slightly polluted raw water with $\mathrm{PPFS} / \mathrm{H}_{2} \mathrm{O}_{2}$ coagulation oxidation coupling technology. The results showed that Fenton reaction mechanism dominates in acid medium; the PPFs coagulation sedimentation dominates in alkaline medium. In this paper, the Removal of Aromatic Hydrocarbons Pollutants from wastewater COD by oxidation coagulation process is studied qualitatively and quantitatively, which has great theoretical and practical guiding significance for screening reagent and improving COD removal rate of wastewater.

\section{Experimental part}

\section{Chemicals}

Coagulant $1 \#$ and oxidation agent $1 \#$ (industrial grade), sulfuric acid (AR), silver sulfate(AR), mercury sulfate(AR), potassium dichromate(AR), sulfate ammonium sulfate(AR), ferrous sulfate(AR), 1,10-phenanthroline(AR), potassium hydrogen phthalate(AR), sodium chloride(AR), n-hexane(AR), Redistilled isooctane (AR) etc.

\section{Instrument}

Agilent Technologies 7890A GC System, separatory funnel, thermostatic bath, COD thermostatic heater etc.

\section{Experimental method}

(1) COD determination: determine COD before and after treating wastewater from an oil field is based on the the national standard GB $119141989^{[12]}$, and the original COD is $308.11 \mathrm{mg} / \mathrm{l}$.

(2) The extraction of organic compounds in wastewater: aromatic hydrocarbons are extracted from the wastewater before and after the wastewater treatment and the qualitative and quantitative analysis is made. Extraction method: join $100 \mathrm{ml}-200 \mathrm{ml}$ water sample in the separatory funnel , twice adding a total of $50 \mathrm{ml}$ hexane or dichloromethane extract organic matter, then is concentrated till the solvent is volatilized completely.

(3) Determination of the organic matter in the wastewater: take a certain amount of dry organic matter to the chromatographic bottle. Prepare sample with $5 \mathrm{mg} / \mathrm{ml}$ dichloromethane and adding aromatic hydrocarbons standard matter D10- anthracene $(0.124 \mathrm{mg} / \mathrm{ml}) 30 \mu 1$. According to literature ${ }^{[13-18]}$, the species and content of organic compounds in water samples before and after the treatment was determined by GC-MS. 


\section{GC-MS condition}

(1) Chromatographic conditions

Agilent HP-5MS chromatographic column 1\# $(30 \mathrm{~m} \times 250 \mu \mathrm{m} \times 0.25 \mu \mathrm{m})$, Agilent 19091S-436UIHP-5MS chromatographic column $2 \#(60 \mathrm{~m} \times 250 \mu \mathrm{m} \times 0.25 \mu \mathrm{m})$; temperature: $50^{\circ} \mathrm{C}$ for 1 minute, up to $100^{\circ} \mathrm{C}$ at the rate of $20^{\circ} \mathrm{C} / \mathrm{min}$, up to $315^{\circ} \mathrm{C}$ at the rate of $3^{\circ} \mathrm{C} / \mathrm{min}$, for $28.5 \mathrm{~min}$; carrier gas: high pure helium, the total flow rate $34 \mathrm{ml} / \mathrm{min}$; shunt ratio of $15: 1$, shunt flow $14.89 \mathrm{ml} / \mathrm{min}$.

(2) Mass spectrometry conditions

The ion source temperature of $230^{\circ} \mathrm{C}$, quadrupole temperature of $150^{\circ} \mathrm{C}$, EMV mode: gain factor; gain factor: 1; EM voltage: 1765; solvent delay 10min; scanning range m/z50 550.

\section{Result and Discussion}

\section{Quantitative on organics in wastewater before and after oxidation treatment}

4 samples of wastewater $150 \mathrm{ml}$ were added into different dosage $(\%, \mathrm{~V} / \mathrm{V})$ of oxidant $1 \#$, then stir for $10 \mathrm{~min}$ at $100 \mathrm{rpm}$ and settle down quiescently for $45 \mathrm{~min}$, then take $100 \mathrm{ml}$ supernatant, and extract and analyze it according to the method described above (as of 2.3,2.4),Take phenanthrene organic compounds in the wastewater, the molecular ion peaks of phenanthrene aromatic hydrocarbons organics in wastewater are shown in figure $1 \sim$ figure 4 before and after treatment. Phenanthrene aromatic hydrocarbons mainly include phenanthrene (P), 1-methyl phenanthrene(1-MP), 2-methylphenanthrene(2-MP), 3-methyl phenanthrene(3-MP) in wastewater, and their mass charge ratio are 178, 192, 206, 220 respectively. The quantitative results of main components before and after oxidation of aromatic hydrocarbons in wastewater are shown in table 1-table 4.

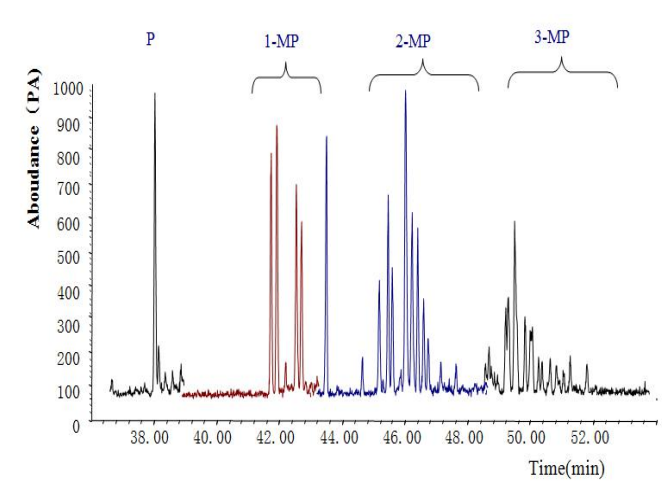

Fig.1 Phenanthrene organic compounds mass mass spectrogram of wastewater

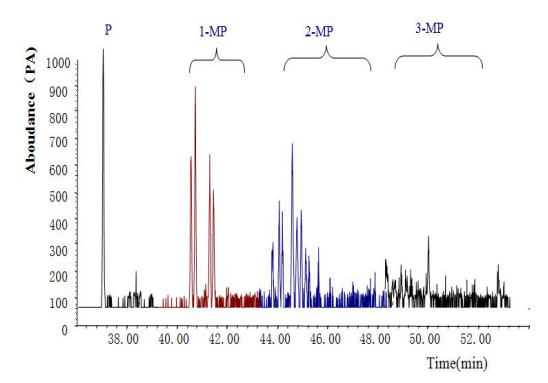

Fig.3 Phenanthrene organic compounds mass spectrogram of wastewater with oxidant $1 \# 5 \%$

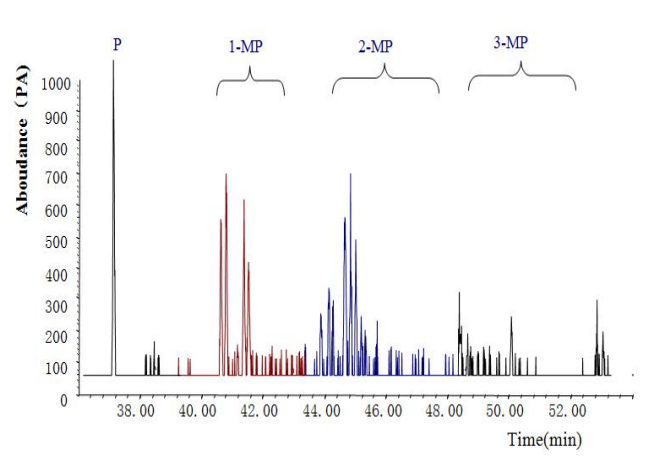

Fig. 2 Phenanthrene organic compounds spectrogram after treatment with $1 \# 1 \%$

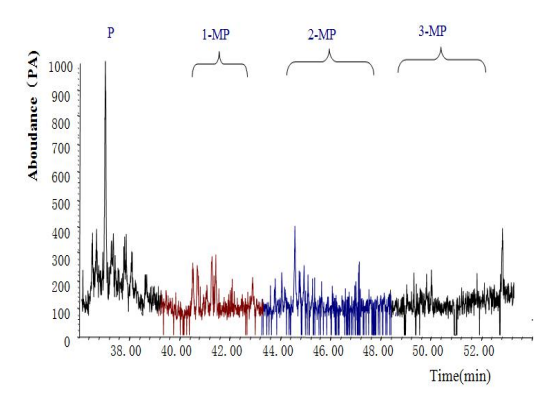

Fig.4 Phenanthrene organic compounds mass spectrogram after treatment with oxidant $1 \# 7 \%$ 
Table 1 Comparison of dicyclic aromatic hydrocarbons content in wastewater before and after oxidation treatment

\begin{tabular}{|c|c|c|c|c|c|c|}
\hline \multirow{2}{*}{$\begin{array}{c}\text { Organics } \\
\text { classification }\end{array}$} & \multirow{2}{*}{$\begin{array}{l}\text { Composition and } \\
\text { content }\end{array}$} & \multirow{2}{*}{$\begin{array}{l}\text { Content in } \\
\text { waste } \\
\text { water/ } \mu \mathrm{g} / \mathrm{L}\end{array}$} & \multicolumn{3}{|c|}{ Oxidant 1\# dosage/\% (V/V) } & \multirow{2}{*}{$\begin{array}{l}\text { Maximum } \\
\text { removal } \\
\text { rate } / \%\end{array}$} \\
\hline & & & 1 & 5 & 7 & \\
\hline \multirow{5}{*}{$\begin{array}{c}\text { Dicyclic } \\
\text { aromatic } \\
\text { hydrocarbon }\end{array}$} & $\begin{array}{l}\text { Naphthalene and } \\
\text { itsderivatives/ } \mu \mathrm{g} / \mathrm{L}\end{array}$ & 2912.84 & 1921.15 & 853.99 & 807.63 & 72.27 \\
\hline & $\begin{array}{l}\text { Biphenyl and its } \\
\text { derivatives } / \mu \mathrm{g} / \mathrm{L}\end{array}$ & 441.13 & 434.35 & 237.82 & 219.82 & 50.17 \\
\hline & $\begin{array}{l}\text { Dibenzothiophene } \\
\text { and its } \\
\text { derivatives/ } \mathrm{mg} / \mathrm{L}\end{array}$ & 19753.12 & 823.2 & 647.68 & 558.80 & 97.17 \\
\hline & $\begin{array}{l}\text { Dibenzofuran and } \\
\text { its derivatives } / \mu \mathrm{g} / \mathrm{L}\end{array}$ & 646.32 & 457.1 & 248.86 & 208.23 & 67.78 \\
\hline & $\begin{array}{l}\text { Fluorene and its } \\
\text { derivatives } / \mu \mathrm{g} / \mathrm{L}\end{array}$ & 819.89 & 795.9 & 743.82 & 515.04 & 37.18 \\
\hline \multicolumn{2}{|c|}{ Total organics content $/ \mu \mathrm{g} / \mathrm{L}$} & 24573.3 & 4431.7 & 2732.17 & $\begin{array}{c}2309.5 \\
2\end{array}$ & 90.60 \\
\hline \multicolumn{2}{|c|}{$\mathrm{COD} / \mathrm{mg} / \mathrm{L}$} & 308.11 & 198.39 & 167.54 & 143.63 & 53.38 \\
\hline
\end{tabular}

Table 1 shows that with the increasing of oxidant $1 \#$ dosage, the total content of bicyclic aromatic hydrocarbons decreased, and with the oxidant $1 \#$ dosage $7 \%(\mathrm{~V} / \mathrm{V})$, total bicyclic aromatic hydrocarbons removal rate reach $90.6 \%$. The removal rate of COD is $53.38 \%$ with the highest the removal rate $97.17 \%$ of dibenzothiophene and its derivatives. The removal rate of fluorene and its derivatives is the lowest $37.18 \%$; The reason is the $\mathrm{C}$ atom in the benzene ring in the structure of fluorene and its derivatives and dibenzothiophene and its derivatives are formed as delta bond by SP2 hybrid orbitals. Electronegativities of S atoms in dibenzothiophene is stronger than $\mathrm{C}$ atoms, which weakens conjugation between the none shared electrons and the ring double bond. The electron density on sulfur atoms increases, increasing the oxidation activity ${ }^{[19,20]}$, so sulfur atoms in dibenzothiophene are easily electrophilic attacked by free radicals in oxidant $1 \#$ to be oxidized and removed.

Table 2 Comparison of triaromatics hydrocarbons content in wastewater

before and after oxidation treatment

\begin{tabular}{|c|c|c|c|c|c|c|}
\hline \multirow{2}{*}{$\begin{array}{c}\text { Organics } \\
\text { classification }\end{array}$} & \multirow{2}{*}{$\begin{array}{l}\text { Composition and } \\
\text { content }\end{array}$} & \multirow{2}{*}{$\begin{array}{c}\text { Content in } \\
\text { waste } \\
\text { water } / \mu \mathrm{g} / \mathrm{L}\end{array}$} & \multicolumn{3}{|c|}{ Oxidant $1 \#$ dosage/\% $(\mathrm{V} / \mathrm{V})$} & \multirow{2}{*}{$\begin{array}{c}\text { Maximum } \\
\text { removal } \\
\text { rate } / \%\end{array}$} \\
\hline & & & 1 & 5 & 7 & \\
\hline \multirow{4}{*}{$\begin{array}{l}\text { Triaromatics } \\
\text { hydrocarbons }\end{array}$} & $\begin{array}{l}\text { phenanthrene and } \\
\text { its derivatives } / \mathrm{ug} / \mathrm{L}\end{array}$ & 8149.81 & 7259 & 6475.65 & 4034.73 & 50.49 \\
\hline & anthracene $/ \mu \mathrm{g} / \mathrm{L}$ & 158.10 & 0 & 0 & 0 & 100 \\
\hline & fluoranthene $/ \mu \mathrm{g} / \mathrm{L}$ & 464.77 & 452.9 & 435.85 & 364.21 & 21.64 \\
\hline & benzofluorene/ $\mu \mathrm{g} / \mathrm{L}$ & 234.36 & 220.5 & 191.13 & 151.82 & 35.22 \\
\hline \multirow{2}{*}{\multicolumn{2}{|c|}{$\begin{array}{l}\text { Total organics content } / \mu \mathrm{g} / \mathrm{L} \\
\qquad \mathrm{COD} / \mathrm{mg} / \mathrm{L}\end{array}$}} & 9007.04 & 7932.4 & 7102.63 & 4550.76 & 49.48 \\
\hline & & 308.11 & 198.39 & 167.54 & 143.63 & 53.38 \\
\hline
\end{tabular}

From table 2, we can see that with the increase of the dosage of oxidant $1 \#$, the total content of triaromatics hydrocarbons decrease, the dosage of oxidant $1 \#$ is $7 \%(\mathrm{~V} / \mathrm{V})$, the total removal rate is $49.48 \%$, and the removal rate of COD is $53.38 \%$. The anthracene removal rate reaches $100 \%$, but the removal rate of fluoranthene is the lowest, only $21.64 \%$; The reason may be the phenyl ring of polycyclic aromatic hydrocarbons in straight line arrangement was more active than the twists and turns arrangement of polycyclic aromatic hydrocarbons in the reaction activity ${ }^{[9,21]}$. All $\mathrm{C}$ and $\mathrm{H}$ atoms of anthracene molecules are arranged in a straight line in the same plane, which leads to active chemical properties, while atoms of fluoranthene molecules are arranged in a corner shape 
cross combinations into different planes, which leads to the structural stability, and isn't as active as anthracene, so removal rate of fluoranthene is low.

Table 3 Comparison of tetra aromatics hydrocarbons content in wastewater

before and after oxidation treatment

\begin{tabular}{|c|c|c|c|c|c|c|}
\hline \multirow{2}{*}{$\begin{array}{c}\text { Organics } \\
\text { classification }\end{array}$} & \multirow{2}{*}{$\begin{array}{l}\text { Composition and } \\
\text { content }\end{array}$} & \multirow{2}{*}{$\begin{array}{l}\text { Content in } \\
\text { wastewater } \\
/ \mu \mathrm{g} / \mathrm{L}\end{array}$} & \multicolumn{3}{|c|}{ Oxidant 1\# dosage/\% $(\mathrm{V} / \mathrm{V})$} & \multirow{2}{*}{$\begin{array}{l}\text { Maximum } \\
\text { removal } \\
\text { rate } / \%\end{array}$} \\
\hline & & & 1 & 5 & 7 & \\
\hline \multirow{4}{*}{$\begin{array}{c}\text { Tetracyclic } \\
\text { aromatics } \\
\text { hydrocarbons }\end{array}$} & $\begin{array}{l}\text { Chrysene and its } \\
\text { derivatives/ } \mu \mathrm{g} / \mathrm{L}\end{array}$ & 1806.97 & 1646.75 & 1638.75 & 1048.71 & 41.96 \\
\hline & benzanthracene $/ \mu \mathrm{g} / \mathrm{L}$ & 106.32 & 105.92 & 105.34 & 63.01 & 40.74 \\
\hline & $\begin{array}{l}\text { Benzo } \\
\text { flouranthene/ } \mu \mathrm{g} / \mathrm{L}\end{array}$ & 175.05 & 135.45 & 0 & 0 & 100 \\
\hline & $\begin{array}{l}\text { Pyrene and its } \\
\text { derivatives } / \mu \mathrm{g} / \mathrm{L}\end{array}$ & 3479.21 & 2705.07 & 2618.78 & 2315.07 & 33.46 \\
\hline \multirow{2}{*}{\multicolumn{2}{|c|}{$\begin{array}{c}\text { Total organics content } / \mu \mathrm{g} / \mathrm{L} \\
\mathrm{COD} / \mathrm{mg} / \mathrm{L}\end{array}$}} & 5567.55 & 4593.19 & 4362.87 & 3426.79 & 38.45 \\
\hline & & 308.11 & 198.39 & 167.54 & 143.63 & 53.38 \\
\hline
\end{tabular}

From table 3, we can see that with the increase of the oxidant 1 \# dosage, the total content of tetra aromatics hydrocarbons decreases. With the dosage of oxidant $1 \#$ increasing from $1 \%$ to $7 \%$, the removal rate of total amount of tetra aromatics hydrocarbons is not high, only $38.45 \%$, and the removal rate of COD is $53.38 \%$. The benzofluoranthene removal rate reaches $100 \%$. The possible reason for that is the large relatively stable pi electron conjugated system of chrysene, benzoanthracene while pyrene and benzofluoranthene structure has a five-membered ring, which isn't stable and easily react.

Table 4 Comparison of pentacyclic aromatic hydrocarbonscontent in wastewater before and after oxidation treatment

\begin{tabular}{|c|c|c|c|c|c|c|}
\hline \multirow{2}{*}{$\begin{array}{l}\text { Organic matter } \\
\text { classification }\end{array}$} & \multirow{2}{*}{$\begin{array}{l}\text { Organic matter } \\
\text { classification }\end{array}$} & \multirow{2}{*}{$\begin{array}{c}\text { Content in } \\
\text { wastewater } \\
/ \mu \mathrm{g} / \mathrm{L}\end{array}$} & \multicolumn{3}{|c|}{ Oxidant $1 \#$ dosage $/ \%(\mathrm{~V} / \mathrm{V})$} & \multirow{2}{*}{$\begin{array}{l}\text { Maximum } \\
\text { removal } \\
\text { rate } / \%\end{array}$} \\
\hline & & & 1 & 5 & 7 & \\
\hline \multirow{2}{*}{$\begin{array}{c}\text { Pentacyclic } \\
\text { aromatichydrocarb } \\
\text { ons }\end{array}$} & $\begin{array}{l}\text { Benzopyrene } / \mu \\
\mathrm{g} / \mathrm{L}\end{array}$ & 293.97 & 284.55 & 0 & 0 & 100 \\
\hline & $\begin{array}{c}\text { Perylene and } \\
\text { its derivatives } \\
/ \mu \mathrm{g} / \mathrm{L}\end{array}$ & 109.42 & 0 & 0 & 0 & 100 \\
\hline \multirow{2}{*}{\multicolumn{2}{|c|}{$\begin{array}{l}\text { Total organic matter content } / \mu \mathrm{g} / \mathrm{L} \\
\mathrm{COD} / \mathrm{mg} / \mathrm{L}\end{array}$}} & 403.39 & 284.55 & 0 & 0 & 100 \\
\hline & & 308.11 & 198.39 & 167.54 & 143.63 & 53.38 \\
\hline
\end{tabular}

Table 4 shows that with the increase of oxidant $1 \#$ dosage, the total content of pentacyclic aromatic hydrocarbons decreases. When the oxidant $1 \#$ dosage is $5 \%(\mathrm{~V} / \mathrm{V})$, the removal rate of pentacyclic aromatic hydrocarbons total content reaches $100 \%$. The reason is that the perylene molecules are coplanar and the structure of perylene is easily modified to react because of its chemical activity while 1, 6, 12 carbon bit of benzopyrene has a lot of negative charges which are more easily oxidized and is conducive to be electrophilic attacked by free radicals.

Table 1 Table 4 data shows that with the oxidant dosage of $7 \% 1 \#(\mathrm{~V} / \mathrm{V})$, the difficulty of the removal of different organic matter is as follows: tetracyclic aromatic hydrocarbons $(38.45 \%)>$ tricyclic aromatic hydrocarbons $(49.48 \%)>$ ring aromatic hydrocarbons $(90.6 \%)>$ five aromatic hydrocarbons ((100\%), and the highest COD removal rate is $53.38 \%$, This suggests that the residual COD may be produced mainly residues of the tetracyclic aromatics hydrocarbons and a small number of Triaromatics hydrocarbons \& dicyclic aromatic hydrocarbon in wastewater.

From Figure $1 \sim$ Figure 4 , we can see that raw water contained more organic molecular ion peak abundance but some of the molecular ion peak abundances reduce or disappear, and also new molecular ion peaks are produced by being treated with different amounts of oxidant 1\#, which 
indicates that the organic matter in water is partially degraded or completely removed under the action of oxidant1 \#.

From Figure $1 \sim$ Figure 4 , the mass chromatogram of molecular ion peak of phenanthrene organics containing in raw water have higher abundance, after treatment with different dosage of oxidant1\#, in addition to P, the compounds of 1-MP, 2-MP, 3-MP mass chromatography molecular ion peak abundance decreased, but also the molecular ion peak of new generated, and this show that the organic in water are partially degraded or completely removed under the function of free radical, nascent state $\mathrm{O}$ produced by the oxidant $1 \#$.

\section{Quantitative on the organic matter in wastewater before and after coagulation treatment}

4 samples of wastewater $150 \mathrm{ml}$ are added to different dosage $(\%, \mathrm{~V} / \mathrm{V})$ of coagulant $1 \#$, then stir for $10 \mathrm{~min}$ at $100 \mathrm{rpm}$ and settle down quiescently for $45 \mathrm{~min}$, then take $100 \mathrm{ml}$ supernatant, and extract and analyze it according to the method described above (as of 2.3,2.4). Take phenanthrene organic compounds in the wastewater, the molecular ion peaks of phenanthrene aromatic hydrocarbons organics (P、1-MP 、2-MP、3-MP) in wastewater are shown in figure 5 figure 7 after treatment, and their mass charge ratio are 178, 192, 206, 220 respectively. The quantitative results of main components before and after coagulation treatment of aromatic hydrocarbons in wastewater are shown in table 5-table8.

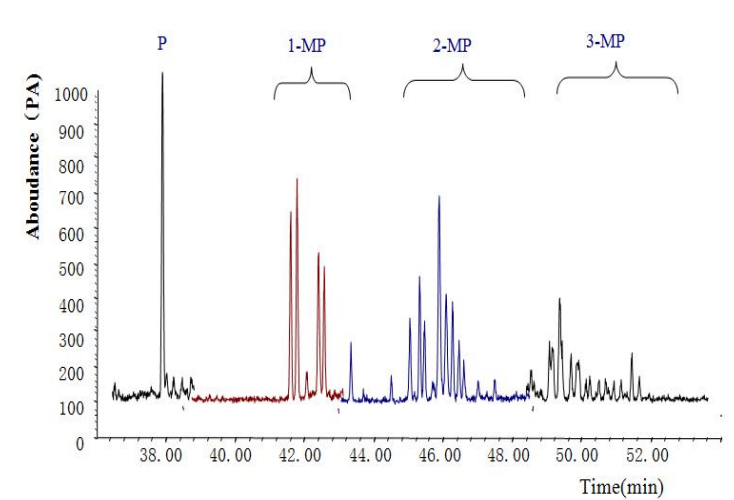

Fig.5 Phenanthrene organic compounds mass spectrogram of wastewater with coagulant $1 \# 1 \%$

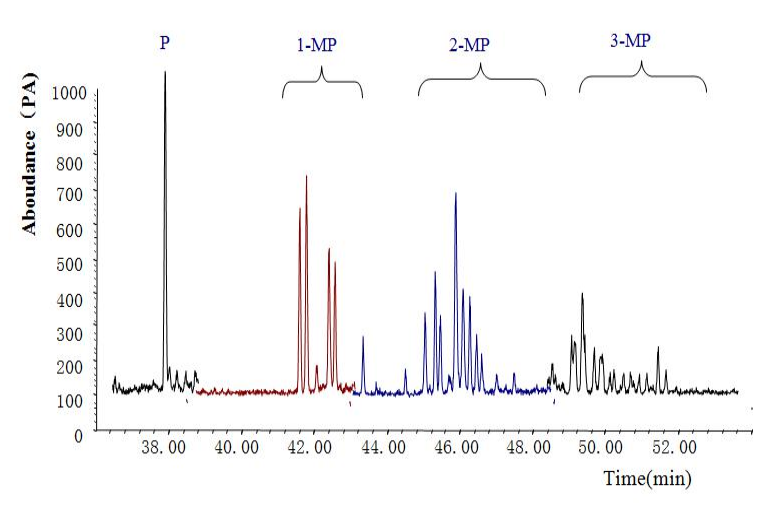

Fig.6 Phenanthrene organic compounds mass $\%$ spectrogram after treatment with coagulant $1 \# 3 \%$

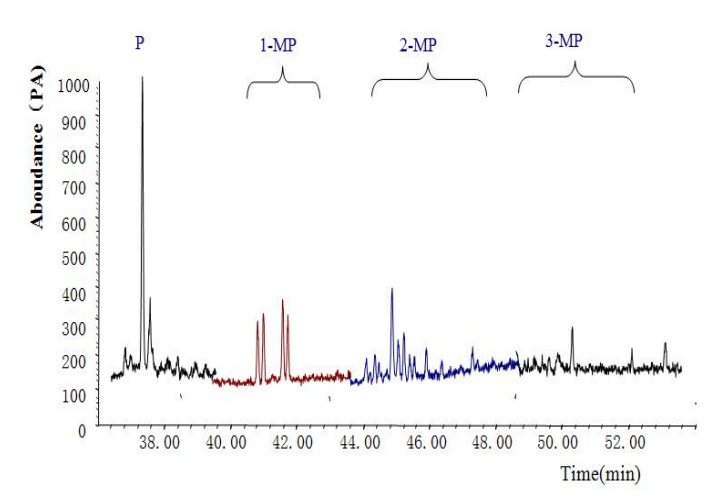

Fig.7 Phenanthrene organic compounds mass spectrogram of wastewater with coagulant $1 \# 5 \%$

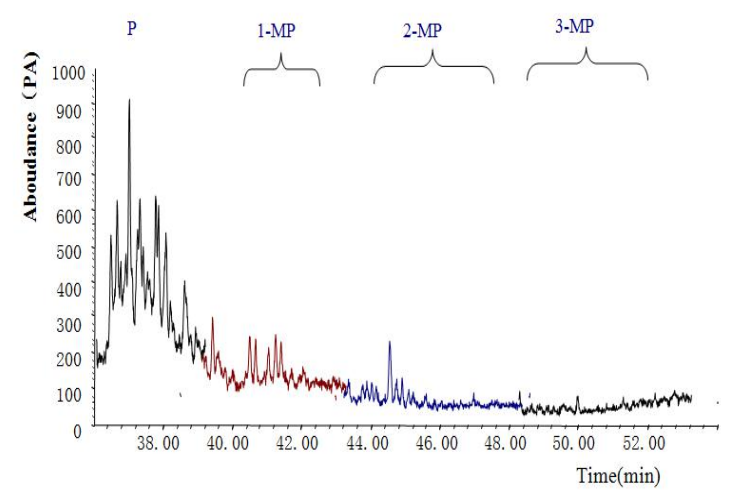

Fig.8 Phenanthrene organic compounds mass spectrogram after treatment with coagulant $1 \#$ $5 \%$ \& oxidant $1 \# 5 \%$ 
Table 5 Comparison of wastewater in bicyclic aromatic hydrocarbons content before and after coagulation treatment

\begin{tabular}{|c|c|c|c|c|c|c|}
\hline \multirow{2}{*}{$\begin{array}{l}\text { Organics } \\
\text { classification }\end{array}$} & \multirow{2}{*}{$\begin{array}{l}\text { Component and } \\
\text { content }\end{array}$} & \multirow{2}{*}{$\begin{array}{l}\text { Content in } \\
\text { waste } \\
\text { water } / \mu \mathrm{g} / \mathrm{L}\end{array}$} & \multicolumn{3}{|c|}{$\begin{array}{c}\text { Coagulant } 1 \# \text { dosage } / \% \\
(\mathrm{~V} / \mathrm{V})\end{array}$} & \multirow{2}{*}{$\begin{array}{l}\text { Maximum } \\
\text { removal } \\
\text { rate } / \%\end{array}$} \\
\hline & & & 1 & 3 & 5 & \\
\hline \multirow{5}{*}{$\begin{array}{c}\text { Dicyclic } \\
\text { aromatic } \\
\text { hydrocarbon }\end{array}$} & $\begin{array}{l}\text { Naphthalene and } \\
\text { itsderivatives } / \mu \mathrm{g} / \mathrm{L}\end{array}$ & 2912.84 & 1475.80 & 1452.55 & 921.89 & 68.35 \\
\hline & $\begin{array}{l}\text { Biphenyl and its } \\
\text { derivatives/ } \mu \mathrm{g} / \mathrm{L}\end{array}$ & 441.13 & 254.80 & 188.15 & 149.84 & 66.03 \\
\hline & $\begin{array}{l}\text { Dibenzothiophene } \\
\text { and its } \\
\text { derivatives/ } \mu \mathrm{g} / \mathrm{L}\end{array}$ & 19753.12 & 5238.26 & 5107.84 & 5038.02 & 74.50 \\
\hline & $\begin{array}{l}\text { Dibenzofuran and } \\
\text { its } \\
\text { derivatives } / \mu \mathrm{g} / \mathrm{L}\end{array}$ & 646.32 & 388.61 & 255.37 & 230.36 & 64.36 \\
\hline & $\begin{array}{l}\text { Fluorene and its } \\
\text { derivatives } / \mu \mathrm{g} / \mathrm{L}\end{array}$ & 819.89 & 799.62 & 350.32 & 209.88 & 74.40 \\
\hline \multicolumn{2}{|c|}{ Total organics content $/ \mu \mathrm{g} / \mathrm{L}$} & 24573.3 & 8110.97 & 7354.23 & 6549.99 & 73.35 \\
\hline \multicolumn{2}{|c|}{$\mathrm{COD} / \mathrm{mg} / \mathrm{L}$} & 308.11 & 240.16 & 204.13 & 176.30 & 42.78 \\
\hline
\end{tabular}

Table 5 shows that with the increase of coagulant 1\# dosage, total content of bicyclic aromatic hydrocarbons declines. When the coagulant $1 \#$ dosage is $5 \%(\mathrm{~V} / \mathrm{V})$, total bicyclic aromatic hydrocarbons removal rate reaches $73.35 \%$ and the removal rate of COD is $42.78 \%$. Dibenzothiophene and its derivatives have the most residual amount, but the removal rate is also the highest. The effect is not as good as that of oxidation treatment. The possible reason is that S atoms in the molecule of dibenzothiophene and its derivatives leads to the large molecular electron cloud density, which is conducive to the adsorption and desorption of the coagulant which is removed by the adsorption settlement of the flocculation.

Table 6 Comparison of triaromatics hydrocarbons content in wastewater before and after coagulation treatment

\begin{tabular}{|c|c|c|c|c|c|c|}
\hline \multirow{2}{*}{$\begin{array}{c}\text { Organics } \\
\text { classification }\end{array}$} & \multirow{2}{*}{$\begin{array}{c}\text { Component and } \\
\text { content }\end{array}$} & \multirow{2}{*}{$\begin{array}{c}\text { Content in } \\
\text { waste } \\
\text { water } / \mu \mathrm{g} / \mathrm{L}\end{array}$} & \multicolumn{3}{|c|}{$\begin{array}{l}\text { Coagulant } 1 \# \text { dosage } / \% \\
(\mathrm{~V} / \mathrm{V})\end{array}$} & \multirow{2}{*}{$\begin{array}{l}\text { Maximum } \\
\text { removal } \\
\text { rate } / \%\end{array}$} \\
\hline & & & 1 & 3 & 5 & \\
\hline \multirow{4}{*}{$\begin{array}{l}\text { Triaromatics } \\
\text { hydrocarbons }\end{array}$} & $\begin{array}{l}\text { Phenanthrene and } \\
\text { its derivatives } / \mu \mathrm{g} / \mathrm{L}\end{array}$ & 8149.81 & 1772.81 & 1532.69 & 1261.54 & 84.52 \\
\hline & Anthracene $/ \mu \mathrm{g} / \mathrm{L}$ & 158.10 & 152.07 & 62.94 & 55.32 & 65.01 \\
\hline & Fluoranthene $/ \mu \mathrm{g} / \mathrm{L}$ & 464.77 & 250.04 & 212.76 & 189.01 & 59.33 \\
\hline & Benzofluorene $/ \mu \mathrm{g} / \mathrm{L}$ & 234.36 & 71.57 & 58.78 & 48.95 & 79.11 \\
\hline \multicolumn{2}{|c|}{ Total organics content $/ \mu \mathrm{g} / \mathrm{L}$} & 9007.04 & 2246.49 & 1867.17 & 1554.82 & 82.74 \\
\hline \multicolumn{2}{|c|}{$\mathrm{COD} / \mathrm{mg} / \mathrm{L}$} & 308.11 & 240.16 & 204.13 & 176.30 & 42.78 \\
\hline
\end{tabular}

From table 6 , we can see that with the increase of coagulant $1 \#$ dosage, the total content of tricyclic aromatic hydrocarbons decreases. When the dosage of coagulant $1 \#$ is $5 \%(\mathrm{~V} / \mathrm{V})$, the total tricyclic aromatic hydrocarbon removal rate reaches $82.74 \%$ and removal rate of COD was $42.78 \%$; Among them, the removal rate of the phenanthrene and its derivatives is the highest and reaches 
$84.52 \%$, which is better than the oxidation treatment effect.

Table 7 Comparison of tetraaromatics hydrocarbons content in wastewater before and after coagulation treatment

\begin{tabular}{|c|c|c|c|c|c|c|}
\hline \multirow{2}{*}{$\begin{array}{c}\text { Organics } \\
\text { classification }\end{array}$} & \multirow{2}{*}{$\begin{array}{c}\text { Component and } \\
\text { content }\end{array}$} & \multirow{2}{*}{$\begin{array}{c}\text { Content in } \\
\text { waste } \\
\text { water } / \mu \mathrm{g} / \mathrm{L}\end{array}$} & \multicolumn{3}{|c|}{ Coagulant $1 \#$ dosage $/ \%(\mathrm{~V} / \mathrm{V})$} & \multirow{2}{*}{$\begin{array}{c}\text { Maximum } \\
\text { removal } \\
\text { rate } / \%\end{array}$} \\
\hline & & & 1 & 3 & 5 & \\
\hline \multirow{4}{*}{$\begin{array}{c}\text { Tetra } \\
\text { aromatics } \\
\text { hydrocarbons }\end{array}$} & $\begin{array}{l}\text { Chrysene and its } \\
\text { derivatives } / \mu \mathrm{g} / \mathrm{L}\end{array}$ & 1806.97 & 173.72 & 154.60 & 144.19 & 92.02 \\
\hline & $\begin{array}{c}\text { Benzanthracene } \\
/ \mu \mathrm{g} / \mathrm{L}\end{array}$ & 106.32 & 29.16 & 28.59 & 22.34 & 78.99 \\
\hline & $\begin{array}{c}\text { Benzo } \\
\text { flouranthene } / \mu \mathrm{g} / \mathrm{L}\end{array}$ & 175.05 & 66.76 & 51.10 & 42.80 & 75.55 \\
\hline & $\begin{array}{c}\text { Pyrene and its } \\
\text { derivatives } / \mu \mathrm{g} / \mathrm{L}\end{array}$ & 3479.21 & 1501.73 & 1227.63 & 1186.24 & 65.90 \\
\hline \multicolumn{2}{|c|}{ Total organics content $/ \mu \mathrm{g} / \mathrm{L}$} & 5567.55 & 1771.37 & 1461.92 & 1395.57 & 74.93 \\
\hline \multicolumn{2}{|c|}{$\mathrm{COD} / \mathrm{mg} / \mathrm{L}$} & 308.11 & 240.16 & 204.13 & 176.30 & 42.78 \\
\hline
\end{tabular}

Table 7 shows that with the increase of coagulant $1 \#$ dosage, the total content of tetracyclic aromatic hydrocarbon decreases. When the dosage of coagulant $1 \#$ is $5 \%(\mathrm{~V} / \mathrm{V})$, the total tetracyclic aromatic hydrocarbon removal rate reaches $74.93 \%$ and removal rate of COD is $42.78 \%$; Among them, the removal rate of chrysene and its derivatives is the highest and reaches $92.02 \%$, which is better than the oxidation treatment effect.

Table 8 Comparison of pentacyclic aromatic hydrocarbonscontent in wastewater before and after coagulation treatment

\begin{tabular}{|c|c|c|c|c|c|c|}
\hline \multirow{2}{*}{$\begin{array}{l}\text { Organics } \\
\text { classificati } \\
\text { on } \\
\end{array}$} & \multirow{2}{*}{$\begin{array}{l}\text { Component and } \\
\text { content }\end{array}$} & \multirow{2}{*}{$\begin{array}{l}\text { Content in } \\
\text { waste } \\
\text { water } / \mu \mathrm{g} / \mathrm{L}\end{array}$} & \multicolumn{2}{|c|}{ Coagulant $1 \#$ dosage $/ \%$} & \multirow{2}{*}{$\frac{(\mathrm{V} / \mathrm{V})}{5}$} & \multirow{2}{*}{$\begin{array}{c}\text { Maximum } \\
\text { removal rate } \\
/ \%\end{array}$} \\
\hline & & & 1 & 3 & & \\
\hline \multirow{2}{*}{$\begin{array}{l}\text { Pentacyclic } \\
\text { aromatichy } \\
\text { drocarbons }\end{array}$} & $\begin{array}{c}\text { Benzopyrene } \\
/ \mu \mathrm{g} / \mathrm{L}\end{array}$ & 293.97 & 101.71 & 89.62 & 63.95 & 78.25 \\
\hline & $\begin{array}{l}\text { Perylene and its } \\
\text { derivatives } / \mu \mathrm{g} / \mathrm{L}\end{array}$ & 109.42 & 45.94 & 33.17 & 22.23 & 79.68 \\
\hline \multicolumn{2}{|c|}{ Total organics content $/ \mu \mathrm{g} / \mathrm{L}$} & 403.39 & 147.65 & 122.79 & 86.18 & 78.64 \\
\hline \multicolumn{2}{|c|}{$\mathrm{COD} / \mathrm{mg} / \mathrm{L}$} & 308.11 & 240.16 & 204.13 & 176.3 & 42.78 \\
\hline
\end{tabular}

From table 8 we can see that with the increase of coagulant $1 \#$ dosage, the total content of pentacyclic aromatic hydrocarbons decreases. When the dosage of coagulant $1 \#$ is $5 \%$, total pentacyclic aromatic hydrocarbons removal rate reaches $78.64 \%$ and the removal rate of COD is $42.78 \%$. Two kinds of organic matter removal rate all reach up to $78 \%$. The reason is the more benzene ring in aromatic compound is, the smaller the water solubility number ${ }^{[22-26]}$ is and the lower the organic polar is, which more easily removed organic matter in wastewater with floc through the desorption and adsorption of coagulant $1 \#$, so as to reduce the COD content.

Figure 5 Figure 7 , with the increase of coagulant 1 \# dosage, with the exception of $\mathrm{P}$, the compounds of 1-MP, 2-MP, 3-MP mass chromatography molecular ion peak abundance decrease in wastewater with no new generation of molecular ion peak, which indicates that the Phenanthrene organics in water are partially removed with no degradation under the function of the coagulant $1 \#$. To sum up, removal efficiency of organic compounds in the wastewater with coagulation is decided 
mainly by destabilization, flocculation, aggregation and flocculation, and is related to the solubility (polarity) of organic matter.

\section{Quantitative on the organics in wastewater before and after the treatment of oxidation-coagulation}

$150 \mathrm{ml}$ wastewater is added $1 \%(\mathrm{~V} / \mathrm{V})$ dosage of coagulant $1 \#$ and $5 \%(\mathrm{~V} / \mathrm{V})$ dosage of oxidant $1 \#$, then stir for $10 \mathrm{~min}$ at $100 \mathrm{rpm}$ and settled quiescently for $45 \mathrm{~min}$, then take $100 \mathrm{ml}$ supernatant. and extract and analyze it according to the method described above ( as of 2.3,2.4) . Take phenanthrene organic compounds in the wastewater. the molecular ion peaks of phenanthrene aromatic hydrocarbons organics (P、1-MP 、2-MP 、3-MP) in wastewater after treatment are shown in figure 8 , and their mass charge ratio are 178, 192, 206, 220 respectively. The quantitative results of main aromatic hydrocarbons organics in wastewater before and after oxidation-coagulation treatment are shown in table 9-table12.

Table 9 Comparison of dicyclic aromatic hydrocarbons content in wastewater

before and after oxidation-coagulation treatment

\begin{tabular}{cccccccc}
\hline $\begin{array}{c}\text { Dicyclic aromatic } \\
\text { hydrocarbons }\end{array}$ & $\begin{array}{c}\text { Naphthalene } \\
\text { and its } \\
\text { derivatives }\end{array}$ & $\begin{array}{c}\text { Biphenyl } \\
\text { and its } \\
\text { derivatives }\end{array}$ & $\begin{array}{c}\text { Dibenzothioph } \\
\text {-ene and its } \\
\text { derivatives }\end{array}$ & $\begin{array}{c}\text { Dibenzofur } \\
\text { an and its } \\
\text { derivatives }\end{array}$ & $\begin{array}{c}\text { Fluorene } \\
\text { and its } \\
\text { derivatives }\end{array}$ & $\begin{array}{c}\text { Total orga } \\
\text {-nics cont- } \\
\text { ent } / \mu \mathrm{g} / \mathrm{L}\end{array}$ & $\begin{array}{c}\mathrm{COD} / \\
\mathrm{mg} / \mathrm{L}\end{array}$ \\
\hline $\begin{array}{c}\text { Content in raw } \\
\text { water } / \mu \mathrm{g} / \mathrm{L} \\
\begin{array}{c}\text { Organics } \\
\text { content after }\end{array}\end{array}$ & 2912.84 & 441.13 & 19753.12 & 646.32 & 819.89 & 24573.3 & 308.11 \\
$\begin{array}{c}\text { treatment } / \mu \mathrm{g} / \mathrm{L} \\
\text { Removal rate } / \%\end{array}$ & 823.28 & 41.29 & 5072.25 & 18.25 & 26.33 & 5481.4 & 37.54 \\
\hline
\end{tabular}

Table 10 Comparison of triaromatics hydrocarbons content in wastewater before and after oxidation-coagulation treatment

\begin{tabular}{ccccccc}
\hline $\begin{array}{c}\text { Triaromatics } \\
\text { hydrocarbons }\end{array}$ & $\begin{array}{c}\text { Phenanthrene } \\
\text { and its } \\
\text { derivatives }\end{array}$ & Anthracene & Fluoranthene & Benzofluorene & $\begin{array}{c}\text { Total } \\
\text { organics } \\
\text { content/ } / \mu \mathrm{g} / \mathrm{L}\end{array}$ & $\begin{array}{c}\mathrm{COD} / \\
\mathrm{mg} / \mathrm{L}\end{array}$ \\
\hline $\begin{array}{c}\text { Content in raw } \\
\text { water } / \mu \mathrm{g} / \mathrm{L} \\
\begin{array}{c}\text { Organics } \\
\text { content after } \\
\text { treatment } \\
/ \mu \mathrm{L} / \mathrm{L}\end{array}\end{array}$ & 8149.81 & 158.1 & 464.77 & 234.36 & 9007.04 & 308.11 \\
$\begin{array}{c}\text { Removal rate } \\
/ \%\end{array}$ & 946.09 & 0 & 186.45 & 0 & 732.54 & 37.54 \\
\hline
\end{tabular}


Table 11 Comparis on of tetra aromatics hydrocarbons content in wastewater before and after oxidation-coagulation treatment

\begin{tabular}{|c|c|c|c|c|c|c|}
\hline $\begin{array}{c}\text { Tetra } \\
\text { aromatics } \\
\text { hydrocarbons }\end{array}$ & $\begin{array}{l}\text { Chrysene } \\
\text { and its } \\
\text { derivatives }\end{array}$ & Benzanthracene & $\begin{array}{c}\text { Benzo } \\
\text { flouranthene }\end{array}$ & $\begin{array}{c}\text { Pyrene } \\
\text { and its } \\
\text { derivatives }\end{array}$ & $\begin{array}{c}\text { Total } \\
\text { organics } \\
\text { content } / \mu \mathrm{g} / \mathrm{L}\end{array}$ & $\begin{array}{l}\mathrm{COD} / \\
\mathrm{mg} / \mathrm{L}\end{array}$ \\
\hline $\begin{array}{c}\text { Content in } \\
\text { raw } \\
\text { water } / \mu \mathrm{g} / \mathrm{L}\end{array}$ & 1806.97 & 106.32 & 175.05 & 3479.21 & 5567.55 & 308.11 \\
\hline $\begin{array}{c}\text { Organics } \\
\text { content after } \\
\text { treatment } \\
/ \mu \mathrm{g} / \mathrm{L}\end{array}$ & 47.44 & 18.21 & 0 & 274.63 & 340.28 & 37.54 \\
\hline$\underset{/ \%}{\text { Removal rate }}$ & 97.37 & 82.87 & 100 & 92.11 & 93.89 & 87.82 \\
\hline
\end{tabular}

Table 12 Comparison of pentacyclic aromatic hydrocarbons content in wastewater before and after oxidation-coagulation treatment

\begin{tabular}{ccccc}
\hline $\begin{array}{c}\text { Pentacyclic } \\
\text { aromatichydrocarbons }\end{array}$ & Benzopyrene & $\begin{array}{c}\text { Perylene and } \\
\text { its derivatives }\end{array}$ & $\begin{array}{c}\text { Total organics } \\
\text { content } / \mu \mathrm{g} / \mathrm{L}\end{array}$ & $\mathrm{COD} / \mathrm{mg} / \mathrm{L}$ \\
\hline $\begin{array}{c}\text { Content in raw } \\
\text { water } / \mu \mathrm{g} / \mathrm{L} \\
\begin{array}{c}\text { Organics } \\
\text { content after treatment } \\
/ \mu \mathrm{g} / \mathrm{L}\end{array}\end{array}$ & 293.97 & 109.42 & 403.39 & 308.11 \\
\begin{tabular}{c} 
Removal rate $/ \%$ \\
\hline
\end{tabular} & 100 & 100 & 0 & 37.54 \\
\hline
\end{tabular}

From the table 9- table 12, we can see that after oxidation-coagulation treatment, the removal rate of the total dicyclic aromatic hydrocarbons reaches $77.69 \%$, the removal rate of dibenzofuran and its derivatives is the highest, and up to $97.18 \%$. The removal rate of total tricyclic aromatic hydrocarbons reaches $91.87 \%$, anthracene and benzofluorene could be completely removed. The removal rate of total tetra aromatics hydrocarbons is $93.89 \%$, the removal rate of chrysene and its derivatives is the highest, and up to $97.37 \%$. The removal rate of the total pentacyclic aromatic hydrocarbons is $100 \%$, and the removal rate of COD reaches up to $87.82 \%$.

Figure 8 shows that compared with the raw water, because of oxidation-coagulation, the mass spectrogram molecular ion peak number and abundance of phenanthrene aromatic hydrocarbons organics (P、1-MP、2-MP、3-MP) change significantly, which shows that the oxidation treating organic wastewater with coagulation, the synergistic effect of coagulation-oxidation can improve processing efficiency. The mechanism may be the combining function of oxidation, substitution, coagulation and desorption, adsorption and precipitation etc.

\section{Conclusion}

(1) From high to low , the content of aromatic hydrocarbons in wastewater is: dicyclic aromatichydrocarbons, triaromatics hydrocarbons, tetra aromatics hydrocarbons,pentacyclic aro-matic hydrocarbons. The main content of organic from high to low is dibenzothiophene andits derivatives,phenanthrene and its derivatives,pyrene and its derivatives ,naphthalene and its derivatives,chrysene and its derivatives,fluorene and its derivatives.

(2) From high to low, the COD removal efficiency of three kinds of method is as follows : 
oxidation-coagulation method, oxidation and coagulation, COD removal efficiency is $87.82 \%$, $53.38 \%, 42.78 \%$, respectively.

(3) When the dosage of oxidant $1 \#$ is $7 \%(\mathrm{~V} / \mathrm{V})$, the dicyclic aromatic hydrocarbons removal rate is $90.6 \%$, the triaromatics hydrocarbons removal rate is $49.48 \%$, the tetra aromatics hydrocarbons removal rate is $38.45 \%$, the pentacyclic aromatics hydrocarbons removal rate is $100 \%$ 。

(4) When the dosage of coagulant $1 \#$ is $5 \%(\mathrm{~V} / \mathrm{V})$, the dicyclic aromatic hydrocarbons removal rate is $73.35 \%$, the triaromatics hydrocarbons removal rate is $82.74 \%$, the tetra aromatics hydrocarbons removal rate is $74.93 \%$, the pentacyclic aromatics hydrocarbons removal rate is $78.64 \%$ 。

( 5 ) $5 \%(\mathrm{~V} / \mathrm{V})$ oxidant $1 \#$ and $5 \%(\mathrm{~V} / \mathrm{V})$ coagulant $1 \#$ are added to treat waste water simultaneously, the dicyclic aromatic hydrocarbons removal rate is $77.69 \%$, the triaromatics hydrocarbons removal rate is $91.87 \%$, the tetra aromatics hydrocarbons removal rate is $93.89 \%$, the pentacyclic aromatics hydrocarbons removal rate is $100 \%$ 。

(6) Oxidant for removing COD in wastewater is mainly through oxidative decomposition, so that organic matter in water partly is degraded or completely removed, and the oxidation is closely related to the molecular structure of organic matter. Coagulant removing organic matter is mainly flocculation, and the adsorption of flocs sedimentation and related to organic matter solubility (polar).

\section{Acknowledgements}

The authors of this work wish to gratefully acknowledge the financial support from the Open Fund of State Key Laboratory of control and treatment of petroleum and petrochemical pollutants (No.2016D500608) .

\section{Reference}

[1]Sun Xiang, Huang Deqing. Flocculation and Dewatering Properties of Sludge Produced from Hypersaline Wastewater Treatm-ent[J]. www.gdchem.com,2013,12(40):135-136.

[2] LiuJinzhi. Data analysis in dye wastewater treatment by oxidationflocculation and adsorp tion methods [D].Shandong Normal University, 2011, 4. (In Chinese)

[3] JINGGuo-lin, GUO Ying-ying, CUI Bao-chen.Explore and Research on Treating Oilfield Wastewater by Flocculation /Oxidation [J].Science Technology and Engineering, 2010,10 (35):8919-8921. (In Chinese)

[4] MiaoZongcheng,Wang Lei, Zhang Yongming,et al. Mechanism of potassium ferrate COD removing effect[J]. Industrial Wate-r Treatment, 2011,31(8):32-34. (In Chinese)

[5] WangYu,JiangYongge, Xu Zheng. StudyontheMechanismforRemovingPAHsfromCoalTarProce ssingWastewaterbyCoagulation [J].JounralofEast ChinaUniversityofScienceandTechnology, 1995, 21(5):600-605. (In Chinese)

[6] LiuJinquan. Studyonthe reactivity and mechanism of chlorine dioxide withpolycyclic aro matic hydrocarbons [J]. Harbin Institute of Technology, 2007,3. (In Chinese)

[7] WangCui,LiuHong,HuKai,et al. Study On the Advanced Treatment of Coking - plant Was tewater by Oxidization-Flocculation[J]. Industrial Safety and Environmental Protection, 2013,39(8):15-18. (In Chinese)

[8] TangJiacui,DingLei,YingYuanyuan,et al. Treatment of bilge oily wastewater by coagulatio $\mathrm{n}$ sedimentation and sodium hypochlorite oxidation[J].Chemical World, 2009:242-245.

[9] $\mathrm{Yu}$ Wei. Study on the treatment of dye wastewater by oxidation-flocculation process [D]. Wuhan University of Science and Technology,2008,11. (In Chinese)

[10] LiuHong, YuWei,LiuJuan,et al. Study on the mechanism of coupled oxidation and floccu lation treatment of acid brilliant scarlet GR[J].Chinese Journal of Environmental Engine ering, 2008,2(8):1040-1043. (In Chinese)

[11] ZhangHuiqin. Study of Effect and Mechanism of Coupled Oxidation and Flocculation P 
rocess in Treating Dye Wastewater and Micro-Polluted Raw Water [D]. Chongqing University,2010. (In Chinese)

[12] GB11914-1989, WaterQuality-Determination of the chemical oxygen Demand-Dichromate method[S].

[13] NiuHongliang,ZhouWei. Determination of Polycyclic Aromatic Hydrocarbons in Lamb K ebabby Gas Chromatography-Mass Spectrometry[J]. Chinese Journal of Spectroscopy La boratory, 2010,27(4):1380-1384. (In Chinese)

[14] S. Orecchio, V. P. Ciotti and L. Culotta.Polycyclic aromatic hydrocarbons (PAHs) incof fee brew samples: Analytical method by GC-MS, profile, levels and sources [J]. Food and Chemical Toxicology, 2009, 47(1): 819-826.

[15] Xianyuan Du, Jianlin Liu, Jing Xin, et al.Polycyclic Aromatic Hydrocarbons(PAHs)in S oil Sampled from an Oilfield: Analytical Method by GC/MS, Distribution,Profile[C]. Jili $\mathrm{n}$ :Sources and Impacts, 2010.

[16] Jing, P., Zheng, J.S., Liu, B., et al. Comparison of solid phase extraction andmedium-p ressure liquid extraction for measuring PAHs in produced water [J]. Journalof Environm ental Monitoring, 2011, 12(1):45-53.

[17]Ping,J., Zheng, J.S., Zhang, B.Y., et al. Gas Chromatography-Mass SpectrometryAnalysis of Polycyclic Aromatics Hydrocarbons (PAHs) in Offshore Produced Water [J]. St. Joh n's Canada: The 64th Canadian Water Resources Association NationalConference, 2011.

[18]Hawboldt K, Chen B,Thanyamanta W, et al. Review of produced watermanagement an challenges in harsh/arctic environments [R].Houston USA:American Bureau of Shipping,2010. [19] GB8978-1996, Integrated wastewater discharge standard[S].

[20] Nyulászi L, Peter Varnai, TamasVeszpremi. Aboutthe aromaticity of five-membered hete rocycles. Journal ofMolecular Structure (Theochem), 1995, 358: 55-61.

[21] OtsukiS,NonakaT,Takashima $N$ et al. Oxidative Desulfurization of Light Gas oil and Vacuum Gas oil by oxidation and Solvent Extraction. Energy\&Fuels,2000,14(6):1232-1239.

[22] K. Hiruta, S. Tokita, T. Tachikawa, et al. Precise PPP molecular orbitalcalculation of t he excitation energies of polycyclic aromatic hydrocarbons.Part 5: Spectroactive portion offluoranthene derivatives. Dyes and Pigments.2000, 44: 123-129.

[23] Zhao B Z,Han T X and Hao X R,et al. Theoretical calculation of the solubility for po lycyclic aromatic hydrocarbons. Journal of Molecular Science, 2004, 20(2):1-4.

[24]Wang Zhansheng,LinRenzi,SunWeilin,et al.Estimation of octanol/water partition coefficient $\mathrm{s}$ of polycyclic aromatic hydrocarbons by gas chromatography[J].Environmental Chemistr y, 2003,22(1):85-88. (In Chinese)

[25] ShenSongmei,CaoXianchong,SongYanhui,etal.The nature and the impact of PAHS[J].Guiz hou Chemical Industry, 2008,33(3):61-63. (In Chinese)

[26] WangLiansheng,WangXiaojiang,XuOuyong,etal.Determination of the n-octanol/water partit ion coefficients of polycyclic aromatic hydrocarbons and estimation of aqueous slubilit ies[J].Acta Scientiae Circumstantiae, 1986,6(4):491-497.

[27] MaJing, Wu Minghong.Physical/ChemicalPropertyEstimationforCl-PAHsCongenersbyQuant itativeStructure-ActivityRelationship[J].Journal of shanghai university (natural science), 20 10,16(5):536-540. 